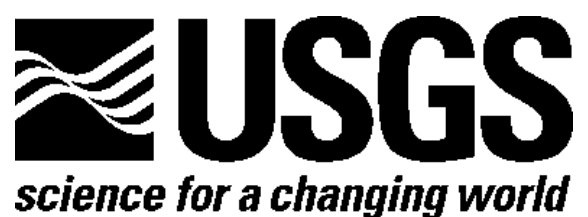

\title{
Engineering and Economics of the USGS Circum-Arctic Oil and Gas Resource Appraisal (CARA) Project
}

By Mahendra K. Verma', Loring P. (Red) White', and Donald L. Gautier ${ }^{3}$

Open-File Report 2008-1193

U.S. Department of the Interior

U.S. Geological Survey

${ }^{1}$ USGS, Central Region, P.O. Box 25046, MS 939, Denver, CO 80225

2USGS, 1321 Cortlandt Street, Houston, TX 77008

${ }^{3}$ USGS, Western Region, 345 Middlefield Road, Menlo Park, CA 94025 


\section{U.S. Department of the Interior DIRK KEMPTHORNE, Secretary}

\section{U.S. Geological Survey \\ Mark D. Myers, Director}

U.S. Geological Survey, Reston, Virginia: 2008

For product and ordering information:

World Wide Web: http://www.usgs.gov/pubprod

Telephone: 1-888-ASK-USGS

For more information on the USGS - the Federal source for science about the Earth, its natural and living resources, natural hazards, and the environment:

World Wide Web: http://www.usgs.gov

Telephone: 1-888-ASK-USGS

Suggested citation:

Verma, M.K., White, L.P., and Gautier, D.L., 2008, Engineering and economics of the USGS circum-arctic oil and gas resource appraisal (CARA) project: U.S. Geological Survey Open-File Report 2008-1193, 17 p.

Any use of trade, product, or firm names, such as Questor of IHS Energy, Inc. and MS Excel, is for descriptive purposes only and does not imply endorsement by the U.S. Government.

Although this report is in the public domain, permission must be secured from the individual copyright owners to reproduce any copyrighted material contained within this report. 


\section{Introduction}

This Open-File report contains illustrative materials, in the form of PowerPoint slides, used for an oral presentation given at the Fourth U.S. Geological Survey Workshop on Reserve Growth of petroleum resources held on March 10-11, 2008. The presentation focused on engineering and economic aspects of the Circum-Arctic Oil and Gas Resource Appraisal (CARA) project, with a special emphasis on the costs related to the development of hypothetical oil and gas fields of different sizes and reservoir characteristics in the North Danmarkshavn Basin off the northeast coast of Greenland.

The individual PowerPoint slides highlight the topics being addressed in an abbreviated format; they are discussed below, and are amplified with additional text as appropriate. Also included in this report are the summary results of a typical "run" to generate the necessary capital and operating costs for the development of an offshore oil field off the northeast coast of Greenland; the data are displayed in MS Excel format generated using Questor software (IHS Energy, Inc.).

U.S. Geological Survey (USGS) acknowledges that this report includes data supplied by IHS Energy, Inc.; Copyright (2008) all rights reserved. IHS Energy has granted USGS the permission to publish this report.

\section{Content of Slides}

Slide 1. - Overall objective of CARA project and the general approach to estimating resource development costs are presented.

Slide 2. - Additional engineering and economic considerations relative to estimating resource development costs are listed. Application of Questor (IHS Energy, Inc.), as an integral part of the resource development study is introduced. Questor generates the following three main parameters that are used to develop resource cost (unit curves) production profile, capital expenditure (CAPEX), and operating expenditure (OPEX). 
Slide 3. - It is pointed out that Questor is directly linked to a large IHS database, which is the source for all the geologic, reservoir, production, and cost data. It also emphasizes that, due to lack of cost data for the Arctic region, some of the costs in Questor's output need to be adjusted to adequately address the unique operating conditions and ice management concerns that impact resource development in the Arctic region. Following are few examples of cost adjustments, made in consultation with the technical group of IHS Energy, Inc.:

1. Drilling rig: (a) consider the option and added expense of using a 'fourth generation' drilling rig, (b) change the floating bare rig unit cost by 10 percent, (c) change the transportation cost by 10 percent, (d) increase the number of drilling days by 15 percent to allow for the extra expense of site preparation, (e) add logging days equal to the number of wells expected to be drilled, and (f) make the cost of Design and Project Management approximately equal to 10 percent of the total drilling cost.

2. Topsides (oil processing facility on top of floating vessel): increase the material cost by 25 percent.

3. Booster pumps: (a) install a pump capable of sustaining a flow of oil for approximately every $200 \mathrm{~km}$ or more as defined by the onshore oil booster pump scheme, (b) add the cost of cable at the rate of $\$ 100 / \mathrm{m}$, (c) calculate the number of days for cable installation by dividing the length of the pipe in $\mathrm{km}$ by 4 , and introduce the cable installation cost (possibly \$200,000/day), and (d) make the Design and Project Management Cost equal to 10 percent of the total cost.

4. Ice management: use the 'special item' in the Field/Project cost under the 'Offshore' tab of the Total Operating Cost Summary for adding possibly as much as $\$ 500,000,000$ per year.

5. Pipelines: (a) insulate all offshore pipes in water depths of more than $200 \mathrm{~m}$, (b) bury pipes where water depths are less than $200 \mathrm{~m}$ to avoid scouring by ice berg, and (c) insulate onshore pipe.

Slide 4. - The main types of data needed for input to Questor are listed. Some of the data are readily available, such as reserve volume, reservoir depth, water depth, and distance to shore. Other parameters are 
calculated from engineering correlations, such as peak field production, gas-oil ratio equation, pressure gradient, and well productivity. In addition, Questor prompts the user to choose a procurement strategy whereby appropriate regions are selected for front-end engineering design (FEED); engineering, procurement, and construction (EPC); and associated cost data.

Slide 5. - A schematic diagram of essential facilities for the drilling, production processing, and transport of crude oil, specific to an offshore field is presented. Questor helps design field development that includes drilling rigs/equipment items; subsea well completion, oil production, and processing facilities (both offshore and offshore); pipelines to transfer the oil from offshore to an export terminal; and booster pumps. With respect to fields off the northeast coast of Greenland, oil processing and transport to market would include the following stages: (a) oil processing offshore with partial stabilization of oil, (b) oil transportation via pipelines to the onshore facility at Flade Budgt where oil is fully stabilized, (c) oil transportation via a subsea pipeline running along the coast to the oil Storage and Export Terminal located at Angmagssalik, and (d) oil tankers are used to transport oil from the Oil Storage and Export Terminal to the New York port for distribution.

Slide 6. - Use of Questor results to estimate resource development costs is described, and the five principal variables -recoverable hydrocarbon volume, well productivity, reservoir/drilling depth, water depth, and distance to shore - that affect the CAPEX and OPEX are listed. The need to apply these variables in a number of different "runs" is emphasized in order to develop statistical cost functions.

Slide 7. - The reports resulting from the use of Questor software are described, and a typical custom report is presented for one development scenario. The report includes, in tabular form, a Summary of all the input data, a Combined Investment and Production Profile, a Combined Cost (CAPEX) Summary and Total Operating Cost Summary.

The PowerPoint slides given below are followed by an Excel spreadsheet. This spreadsheet constitutes a custom report for one of the runs, giving the project summary and combined investment and production profiles, and investment and operating costs. 


\section{Engineering and Economics of the}

USGS Circum-Arctic Oil and Gas Resource Appraisal (CARA)

\section{By}

Mahendra K. Verma

Loring P. (Red) White

Donald L. Gautier

Fourth U.S. Geological Survey Workshop on Reserve Growth

March 10-11, 2008

Denver, Colorado 


\section{Study Objective}

$\checkmark$ The objective of the CARA project is to assess the Arctic region for its hydrocarbon resource volume and its development cost by integrating geologic, engineering and economic (cost) data.

- Geology defines the hydrocarbon volume of a resource.

- Engineering looks at the development strategy.

- Economics (or unit cost curves) defines the value of a resource development. 


\section{Engineering and Economics}

* Hydrocarbon volume along with the following reservoir/engineering and cost data are required for the development of resource cost

(unit) curves:

- Production Profile

- Capital Expenditure (CAPEX)

- Operating Expenditure (OPEX)

* Questor (IHS Inc.) is a tool that generates these above parameters for various field development scenarios. 


\section{Questor's link to a database and policy decisions for better estimates of cost}

$\diamond$ Questor has a direct link to a large database with geologic, reservoir, production and cost data from various countries/regions around the world.

- In consultation with IHS technical support group, certain costs in the Questor were added/increased to account for harsh operating conditions and ice management in the Arctic region. 


\section{Questor and its Input}

- The following parameters are required as an input to Questor:

- Reserve volume

- Reservoir depth

- Reservoir pressure

- Solution gas-oil ratio

- Water depth

- Fluid gravity

- Estimated ultimate recovery per well

- Average well productivity

- Distance to shore 


\section{A schematic of the facility design for an offshore oil field}

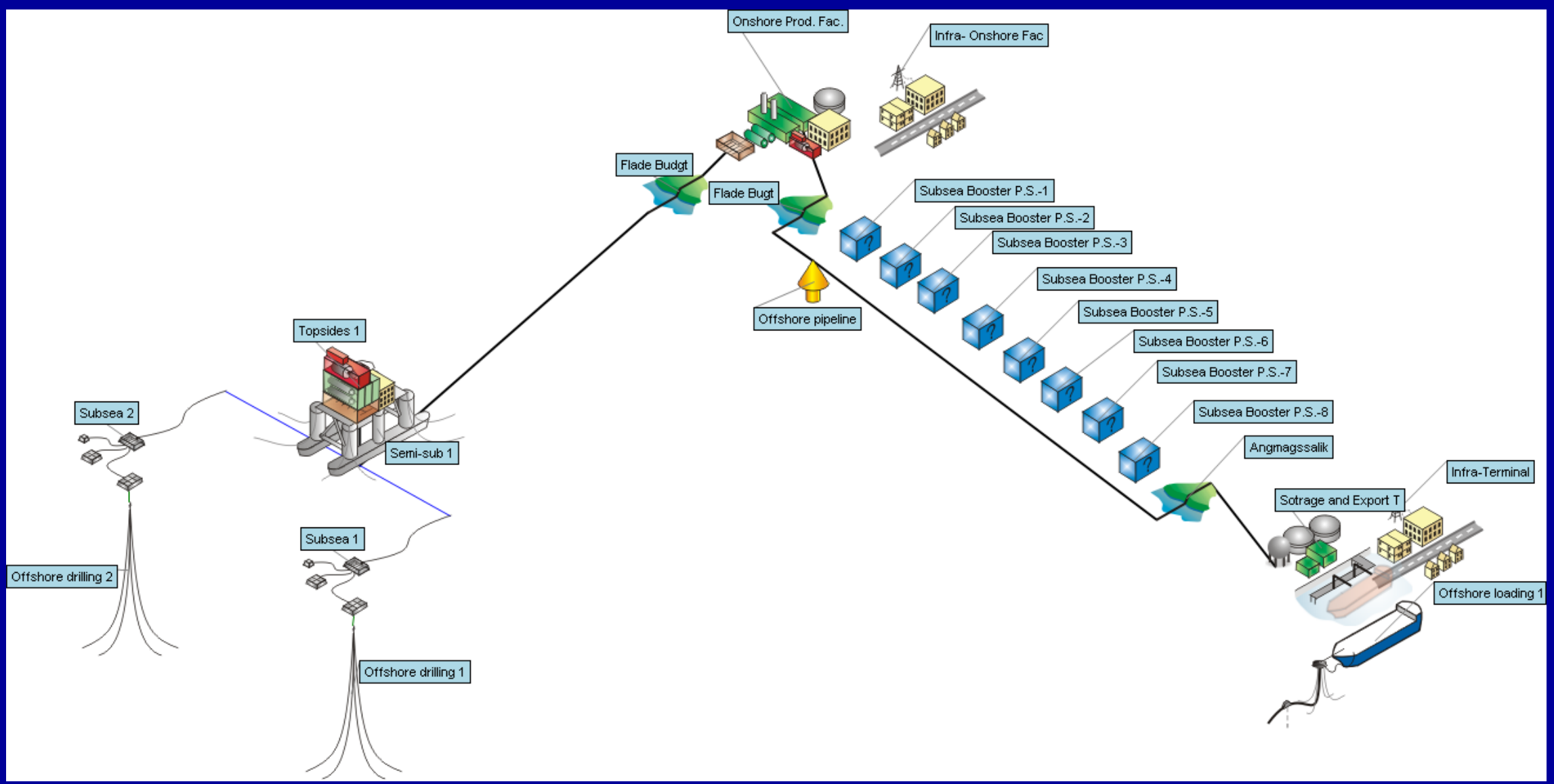




\section{How Questor results are to be used}

to develop resource cost curves?

- Make a number of runs with Questor using a range of values for each of the following variables:

- Reserve volume

- Well productivity

- Reservoir/drilling depth

- Water depth

- Distance to shore

$\checkmark$ Use results from the runs to develop statistical cost functions. 


\section{Results from Questor}

$\downarrow$ Questor allows printing of either detailed or custom reports.

- Detailed report: giving details of CAPEX and OPEX, and a report could be up to 100 s of pages long.

- Custom report: giving Summary sheet, CAPEX and OPEX, making it easier for a review.

A typical custom report in Excel format is presented separately. 
Project name

Country

Region

Basin

Procurement strategy

Offshore

Contingency

Equipment

Materials

Fabrication

Linepipe

Installation

Design \& PM

Opex

Certification

Freight

Technical database

Offshore

Unit set

Development type

Development concept

Overall input

Design oil production flowrate Design associated gas flowrate

Water injection capacity factor

Design water injection flowrate

Design gas injection rate

Gas oil ratio

Design factor

Fluid characteristics

Oil density @ STP

CO2 content

Production profile characteristics

Plateau rate

Productivity

Peak well flow

Maximum drilling stepout

Export methods

Oil export method

Distance to delivery point

Number of wells

Production wells

Water injection wells

Field level miscellaneous data

Distance to operations base

Distance to delivery point

Maximum drilling stepout

Maximum ambient temperature

\begin{tabular}{|l|}
\hline NEG_MKV_OIL_RUN_27B \\
\hline North America Average \\
\hline North America \\
\hline Arctic Ocean Region Average \\
\hline
\end{tabular}

\begin{tabular}{|l|l|r|}
\multicolumn{2}{c}{ Currency } & Rate/\$ \\
\hline North Atlantic Ocean Regi & $\$$ & 1.00 \\
\hline N. North Sea (Norway) & NOK & 5.78 \\
\hline N. North Sea (Norway) & NOK & 5.78 \\
\hline N. North Sea (Norway) & NOK & 5.78 \\
\hline S. E. Asia & US\$ & 1.00 \\
\hline N. North Sea (Norway) & NOK & 5.78 \\
\hline N. North Sea (U.K.) & $£$ & 0.50 \\
\hline N. North Sea (Norway) & NOK & 5.78 \\
\hline N. North Sea (Norway) & NOK & 5.78 \\
\hline N. North Sea (Norway) & NOK & 5.78 \\
\hline N. North Sea (U.K.) & $£$ & 0.50 \\
\hline
\end{tabular}

Procurement strategy

Onshore

Contingency

Equipment

Materials

Prefabrication

Linepipe

Construction

Design \& PM

Certification

Opex

Technical database

Onshore

N. America

N. North Sea (Norway)

\begin{tabular}{|l|}
\hline Oilfield \\
\hline Oil \\
\hline Semi-submersible + Subsea tie-back \\
\hline
\end{tabular}

\begin{tabular}{|l|l|r|}
\multicolumn{2}{c}{ Currency } & Rate $\mathbf{\$}$ \\
\hline North America Average & $\$$ & 1.00 \\
\hline N. America & US\$ & 1.00 \\
\hline Western Europe & US\$ & 1.00 \\
\hline Western Europe & US\$ & 1.00 \\
\hline Asia & US\$ & 1.00 \\
\hline Eastern Europe & US\$ & 1.00 \\
\hline Western Europe & US\$ & 1.00 \\
\hline Western Europe & US\$ & 1.00 \\
\hline Western Europe & US\$ & 1.00 \\
\hline Western Europe & US\$ & 1.00 \\
\hline
\end{tabular}
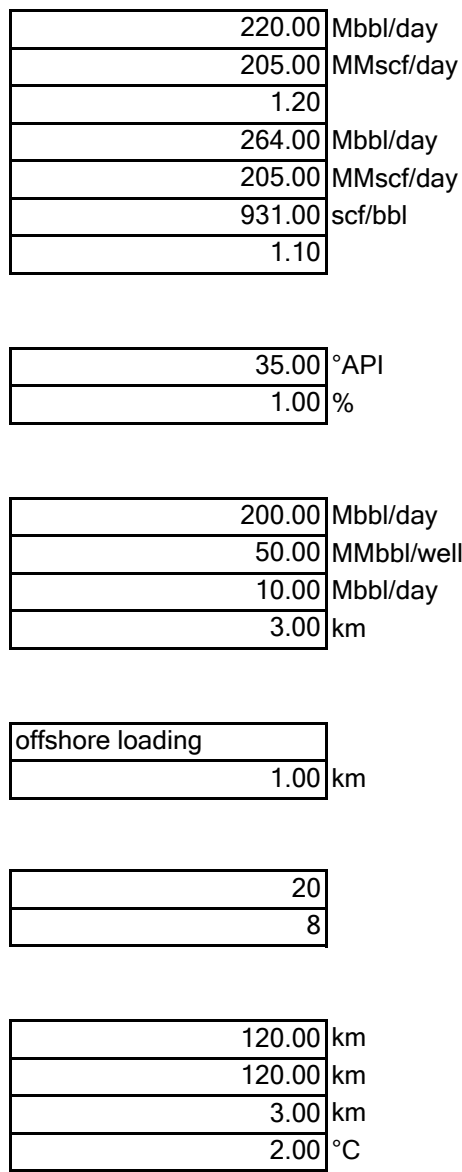

Reserves

Water depth

Reservoir depth

Reservoir pressure

Reservoir length

Reservoir width

H2S content

Gas molecular weight

$10.00 \mathrm{ppm}$ 30.10

Years to plateau

Plateau duration

Field life

Onstream days

Gas export method

Distance to delivery point inject into reservoir

\begin{tabular}{|l|}
\hline inject into reservoir \\
\hline
\end{tabular}

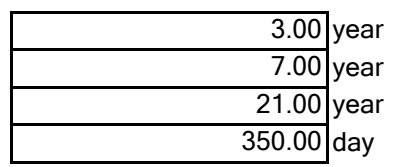

$0.00 \mathrm{~km}$

Gas injection wells 


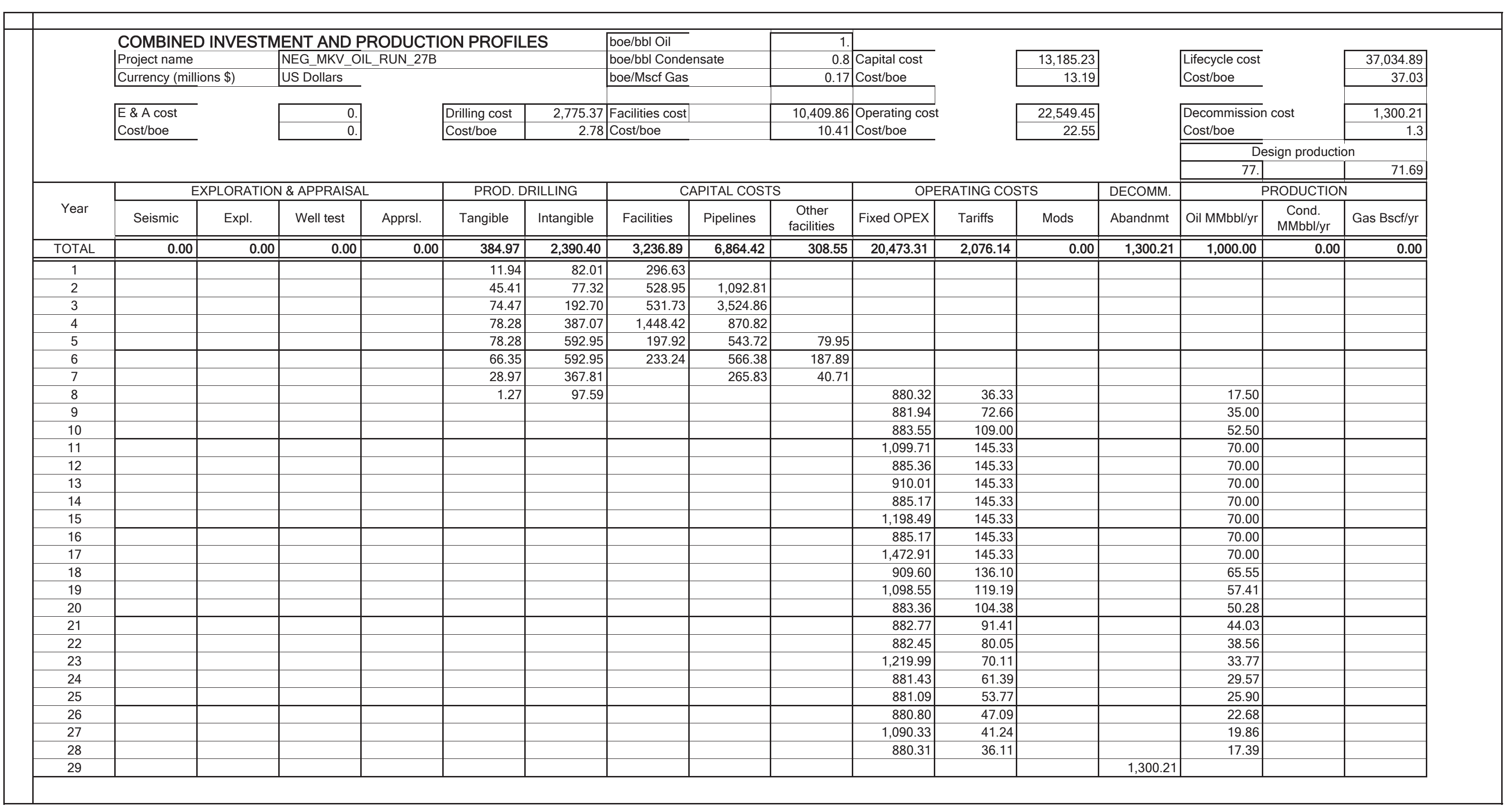


COMBINED COST SUMMARY

\begin{tabular}{|l|r|}
\hline \multicolumn{1}{|c|}{ Project } & NEG_MKV_OIL_RUN_278 \\
\hline \multicolumn{1}{|c|}{ Location } & North America \\
\hline Development type & Oil \\
\hline \multicolumn{2}{|c|}{} \\
\hline Sub total & $11,339,191,000$ \\
\hline Contingency & $1,846,024,000$ \\
\hline Grand total & $13,185,215,000$ \\
\hline
\end{tabular}

\begin{tabular}{|c|c|c|c|c|c|c|c|c|c|c|c|}
\hline tree & Grand total & Equipment & |Materials & Fabrication & Prefabrication & Installation/Construction & |H.U. \& C. & |Design & Project management & cert. & ntingency \\
\hline Topsides 1 & $576,644,000$ & $162,665,000$ & $76,183,000$ & $52,315,000$ & & 0 & 16,230,000 & $153,727,000$ & $38,139,000$ & $24,963,000$ & $52,422,000$ \\
\hline Semi-sub 1 & $786,599,000$ & $562,413,000$ & 19,826,000 & $2,992,000$ & & $8,832,000$ & $4,620,000$ & $12,882,000$ & $12,720,000$ & $31,214,000$ & $131,100,000$ \\
\hline Offshore pipeline 2 & $37,561,000$ & & $2,778,000$ & & & $26,017,000$ & & 616,000 & $1,696,000$ & $1,555,000$ & $4,899,000$ \\
\hline Offshore pipeline 1 & $412,162,000$ & & $185,611,000$ & & & $134,190,000$ & & $5,677,000$ & $15,858,000$ & 17,066,000 & $53,760,000$ \\
\hline \begin{tabular}{|l|} 
Offshore pipeline 3 \\
\end{tabular} & $6,405,489,000$ & & $3,392,620,000$ & & & $1,733,349,000$ & & $47,173,000$ & $131,610,000$ & $265,238,000$ & $835,499,000$ \\
\hline offshore loading 1 & $340,752,000$ & $172,563,000$ & 16,805,000 & & & \begin{tabular}{|l|l|}
$17,330,000$ \\
\end{tabular} & & $\mid \begin{array}{l}17,100,000 \\
\end{array}$ & $46,640,000$ & 13,522,000 & $56,792,000$ \\
\hline Offshore drilling 1 & $1,433,580,000$ & $94,758,000$ & $62,142,000$ & & & $837,422,000$ & & $50,160,000$ & $93,280,000$ & $56,888,000$ & $238,930,000$ \\
\hline Offshore drilling 2 & $1,341,780,000$ & $90,046,000$ & $58,583,000$ & & & $780,660,000$ & & $47,424,000$ & $88,192,000$ & $53,245,000$ & $223,630,000$ \\
\hline Subsea 1 & $276,260,000$ & 73,178,000 & $32,392,000$ & & & 95,485,000 & & $11,924,000$ & $6,275,000$ & $10,963,000$ & $46,043,000$ \\
\hline $\begin{array}{l}\text { Subsea } 2 \\
\end{array}$ & $270,186,000$ & $66,424,000$ & $28,363,000$ & & & $100,603,000$ & & $12,472,000$ & $6,572,000$ & $10,721,000$ & $45,031,000$ \\
\hline Subsea Booster P.S. & $38,569,000$ & $24,051,000$ & $1,395,000$ & 7,000 & & $4,028,000$ & & $1,368,000$ & $2,544,000$ & $1,670,000$ & $3,506,000$ \\
\hline Subsea Booster P.S. & $38,569,000$ & $24,051,000$ & $1,395,000$ & 7,000 & & $4,028,000$ & & $1,368,000$ & $2,544,000$ & $1,670,000$ & $3,506,000$ \\
\hline Subsea Booster P.S. & $38,569,000$ & $24,051,000$ & $1,395,000$ & 7,000 & & $4,028,000$ & & $1,368,000$ & $2,544,000$ & $1,670,000$ & $3,506,000$ \\
\hline Subsea Booster P.S. & $38,569,000$ & $24,051,000$ & $1,395,000$ & 7,000 & & $4,028,000$ & & $1,368,000$ & $2,544,000$ & $1,670,000$ & $3,506,000$ \\
\hline Subsea Booster P.S. & $38,569,000$ & $24,051,000$ & $1,395,000$ & 7,000 & & $4,028,000$ & & $1,368,000$ & $2,544,000$ & $1,670,000$ & $3,506,000$ \\
\hline Subsea Booster P.S. & $38,569,000$ & $24,051,000$ & $1,395,000$ & 7,000 & & $4,028,000$ & & $1,368,000$ & $2,544,000$ & $1,670,000$ & $3,506,000$ \\
\hline Subsea Booster P.S. & $38,569,000$ & $24,051,000$ & $1,395,000$ & 7,000 & & $4,028,000$ & & $1,368,000$ & $2,544,000$ & $1,670,000$ & $3,506,000$ \\
\hline Subsea Booster P.S. & $38,569,000$ & $24,051,000$ & $1,395,000$ & 7,000 & & $4,028,000$ & & $1,368,000$ & $2,544,000$ & $1,670,000$ & $3,506,000$ \\
\hline Onshore Prod. Fac. & $238,798,000$ & $36,882,000$ & $28,523,000$ & & $12,284,000$ & $86,817,000$ & & $25,200,000$ & $13,872,000$ & $4,072,000$ & $31,148,000$ \\
\hline Sotrage and Export T & $516,633,000$ & $35,727,000$ & 59,074,000 & & $13,222,000$ & \begin{tabular}{l|l|}
$230,280,000$ \\
\end{tabular} & & 65,894,000 & $36,240,000$ & $8,809,000$ & $67,387,000$ \\
\hline Onshore pipeline 1 & $3,071,000$ & & $1,001,000$ & & & $1,084,000$ & & 245,000 & 288,000 & 52,000 & 401,000 \\
\hline \begin{tabular}{|l|} 
Onshore pipeline 3 \\
\end{tabular} & $3,071,000$ & & $1,001,000$ & & & $1,084,000$ & & 245,000 & 288,000 & 52,000 & 401,000 \\
\hline \begin{tabular}{|l} 
Onshore pipeline 2 \\
\end{tabular} & $3,071,000$ & & $1,001,000$ & & & $1,084,000$ & & 245,000 & 288,000 & 52,000 & 401,000 \\
\hline Infra- Onshore Fac & $115,503,000$ & & $86,506,000$ & & & & & $5,314,000$ & $6,648,000$ & $1,969,000$ & $15,066,000$ \\
\hline \begin{tabular}{|l|} 
Infra-Terminal \\
\end{tabular} & $115,503,000$ & & $86,506,000$ & & & & & $5,314,000$ & $6,648,000$ & $1,969,000$ & $15,066,000$ \\
\hline$\sqrt{\text { TOTALS }}$ & \begin{tabular}{l|l|}
$13,185,215,000$ \\
\end{tabular} & \begin{tabular}{|c|}
$1,487,064,000$ \\
\end{tabular} & \begin{tabular}{ll|l}
$4,150,075,000$ \\
\end{tabular} & (55,363,000 & 25,506,000 & \begin{tabular}{|l|}
$4,086,461,000$ \\
\end{tabular} & 20,850,000 & \begin{tabular}{l|l|}
$472,556,000$ \\
\end{tabular} & "525,606,000 & |515,710,000 & 1,846,024,000 \\
\hline
\end{tabular}


Total operating cost summary

Grand dotal operating cost
Direct cosst

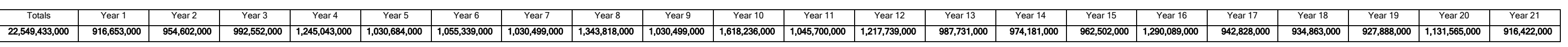

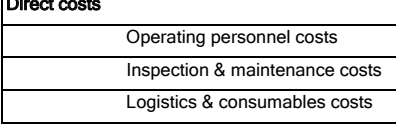

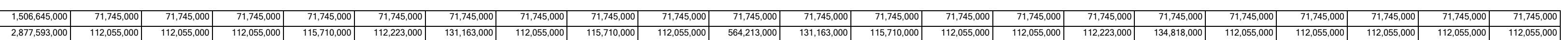

Wellosis 